\title{
Marketing Performance Influenced by Market Orientation Thro-ugh Value Creation
}

\author{
Rizki Zulfikar \\ Department of Business Management \\ Universitas Komputer Indonesia \\ Bandung,Indonesia \\ rizki.zulfikar@email.unikom.ac.id
}

\begin{abstract}
The aim of this research is to find evidence on the impact of market orientation to marketing performance through value creation in small and medium enterprises (SMEs) of knitting industry in Bandung, West Java. The methodology used in this research is descriptive and verification analysis conducted to 281 respondents of SMEs in Sentra Rajut Binong Jati in Bandung. Structural Equation Modeling (SEM) is used in hypothesis's testing using LISREL 8.7 software as the analysis tool in accordance with the research aims. The research result shows that market orientation has no direct impact on marketing performance but has a positive and significant indirect impact to marketing performance with value creation as intervening variable at small and medium enterprises (SMEs) of Binong Jati in Bandung.
\end{abstract}

Keywords - Market Orientation, Value Creation, Marketing Performance, SMEs, Knitting Industry, Binong Jati

\section{INTRODUCTION}

The existence of SMEs (Small and Medium Enterprises) are currently considered to have influenced the growth of economy and become a key factor in promoting private sector developments and partnerships in both developed and developing countries [1]. SMEs help to create jobs and are often seen as important factors for dynamic economic growth and innovation. This business also helps diversify economic activities that have a major contribution to export and import activities. These economic activities are flexible and can adapt quickly to the changes in market demands. Overall, SMEs make a large contribution to the national economy.

An overview has been provided regarding the challenges encountered by textile industry SMEs [2]. He explained that there are currently 5 (five) challenges faced by SMEs in the textile industry, which consists of: (1) human, social and cultural resources: Including family, culture and community problems; (2) logistics and finance: barriers related to machines, rent, electricity and water, transportations and supplies; (3) managerial and marketing: Includes issues related to labor, health, strategy and communication, and competition; (4) technology and knowledge: Highlighted issues such as upgradation, experience, information, and digitalization; (5) government policies: issues such as rebates (discounted prices) and tax policies; and (6) the most urgent problem encountered by the textile industry is the lack of knowledge and poor communication skills.
With the existence of several dynamics, especially in the textile industry, the pressure of competition has become so tight that it directly or indirectly affects the marketing performance of the company greatly, including the SMEs in the textile and apparel industries.

However, in its development it faces several problems which are (1). lack of capital, (2). Marketing difficulties, (3). simple organizational structure with non-standard division of labor, (4). low quality management, (5). limited human resources and (6). low quality, (7). lack of financial statements, (8). weak legal aspects, and (9). low quality of technology. The problems above have become a classic problem for small and medium businesses.

In the city of Bandung there are 2 (two) knitting centers; Sentra Rajut Binong Jati and Sentra Rajut Margasari. Sentra Rajut Binong Jati is the largest of the two centers, the largest in Indonesia and is one of the small home industries that have potential and can contribute to the economy of Bandung City.

The phenomenon related to marketing performance surely indicates that since 2010 - 2014 there are still problems in both centers. Unstable sales volume and still dependent on particular moments and the persistence of consumer complaints certainly need serious attention by the actors in both places. Hence, we need superior value creation for the products given to consumers in order to improve marketing performance.

References [3-5] which states that value creation affects marketing performance. In addition, market orientation is one of the marketing strategies to retain customers. The concept of market orientation is a topic that has been extensively studied, especially in the science of marketing strategies. Various empirical studies related to market orientation have been carried out in various types of industries, both large, medium and small scale. As in the small and medium scale industries, garment manufacturers, constructions, food and beverages, service fields, and technology [6 - 14].

This orientation is considered as the implementation of the marketing concept by emphasizing that consumers are a source of survival for a company. Marketing must use the concept of how companies know what customers / consumers want and fulfill them by putting customer satisfaction and 
values as the main thing and transactions as the basis of analysis [15]. On the other hand, output added from the application of the concept of market orientation, namely: (1) satisfying customers, so that customers would buy again, (2) customers would speak positively about the organization, (3) customers would prioritize the organization compared to another company [16].

Based on the explanation above, the problem can be formulated by drawing the image of market orientation, value creation and marketing performance of small and medium enterprises especially knitting centers in Bandung City and how the market orientation affects marketing performance through value creation.

For companies, the decision to do market orientation, create value for customers, and improve marketing performance is also a scope for strategic marketing discussions even though operational practices are more often discussed in marketing strategies. According to Reed, planning, decision making, and establishng a framework for marketing decision making is part of a holistic approach to the strategic management activities of an organization.

\section{Market Orientation}

Market orientation viewed as the most impactive and efficient organizational culture in shaping the behaviors necessary for the creation of superior value for buyers and thus continuously making superior performance for business. This is certainly different from the construction offered by Kohli \& Jaworski (1990), where the definition above market orientation is more emphasic on behavior consisting of 3 (three) elements, namely: (1) customer orientation; (2) competitor orientation; and (3) interfunctional coordination [17].

Another study stated that market orientation is a company that implements the concept of marketing in order to achieve business goals and objectives by determining customer needs and desires as targets and delivering customer satisfaction more impactively and efficient compared to competitors [18]. The various dimensions described above can be summarized in table 1

TABLE I. MARKET ORIENTATION DIMENSION

\begin{tabular}{|l|l|l|l|l|}
\hline $\begin{array}{l}\text { Hussain } \text { et } \\
\text { al., (2016) }\end{array}$ & $\begin{array}{l}\text { Chung } \\
\mathbf{( 2 0 1 5 )}\end{array}$ & $\begin{array}{l}\text { Njeru \& } \\
\text { Kibera } \\
\mathbf{2 0 1 4 )}\end{array}$ & $\begin{array}{l}\text { Craven \& } \\
\text { Piercy } \\
\mathbf{( 2 0 1 3 )}\end{array}$ & $\begin{array}{l}\text { Serna, } \\
\text { Guzman, } \\
\text { and Castro } \\
\mathbf{( 2 0 1 3 )}\end{array}$ \\
\hline $\begin{array}{l}\text { Customer } \\
\text { Orientation }\end{array}$ & $\begin{array}{l}\text { Quality } \\
\text { Capability }\end{array}$ & $\begin{array}{l}\text { Customer } \\
\text { Orientation }\end{array}$ & $\begin{array}{l}\text { Customer } \\
\text { Focus }\end{array}$ & $\begin{array}{l}\text { Costumer } \\
\text { Orientation }\end{array}$ \\
$\begin{array}{l}\text { Competitor } \\
\text { Orientation }\end{array}$ & $\begin{array}{l}\text { Service } \\
\text { Capability }\end{array}$ & $\begin{array}{l}\text { Competitor } \\
\text { Orientation }\end{array}$ & $\begin{array}{l}\text { Competitor } \\
\text { Intelligence }\end{array}$ & $\begin{array}{l}\text { Competenc } \\
\text { ention } \\
\text { Orientation }\end{array}$ \\
$\begin{array}{l}\text { Inter- } \\
\text { functional } \\
\begin{array}{l}\text { Coordinatio } \\
n\end{array}\end{array}$ & $\begin{array}{l}\text { Cont } \\
\text { control } \\
\text { capability }\end{array}$ & $\begin{array}{l}\text { Inter- } \\
\text { functional } \\
\text { Coordinatio } \\
n\end{array}$ & $\begin{array}{l}\text { Cross- } \\
\text { functional } \\
\text { Coordinatio } \\
n\end{array}$ & $\begin{array}{l}\text { Inter- } \\
\text { functional } \\
\text { Orientation }\end{array}$ \\
\hline
\end{tabular}

\begin{tabular}{|l|l|l|l|l|}
\hline $\begin{array}{l}\text { Hussain } \text { et } \\
\text { al., (2016) }\end{array}$ & $\begin{array}{l}\text { Chung } \\
\mathbf{( 2 0 1 5 )}\end{array}$ & $\begin{array}{l}\text { Njeru \& } \\
\text { Kibera } \\
\mathbf{( 2 0 1 4 )}\end{array}$ & $\begin{array}{l}\text { Craven \& } \\
\text { Piercy } \\
\mathbf{( 2 0 1 3 )}\end{array}$ & $\begin{array}{l}\text { Serna, } \\
\text { Guzman, } \\
\text { and Castro } \\
\text { (2013) }\end{array}$ \\
\hline & $\begin{array}{l}\text { Speed } \\
\text { Capability }\end{array}$ & & $\begin{array}{l}\text { Performance } \\
\text { Implication }\end{array}$ & \\
& $\begin{array}{l} \\
\text { Innovatio } \\
n\end{array}$ & & & \\
& Capability & & & \\
\hline
\end{tabular}

Thus the market orientation in this study uses 3 dimensions namely Market Orientation, Competitor Orientation, and Interfunctional Orientation [17] elaborated from the $[19,20]$. This is due to the lack of capacity of SMEs in the knitting center of Bandung in absorbing and understanding information both about the needs and desires of customers and the strengths and weaknesses of competitors as well as the ability to disseminate that information into functions within the company.

\section{Value Creation}

In marketing, value has been defined in relation to ownership of goods and is referred to as trade-off (exchange) between the benefits obtained from ownership and the sacrifices made to obtain ownership. The concept of value assumes the value contained in products and services, creates value associated with uncovering needs, designing solutions, producing solutions and transferring these solutions to customers in exchange for something else [21].

Lindman defines value creation as the ability of a company to create and deliver value with impactive management of supply chains, shared networks, or customer relationships that form the main source of value creation [22].

References from various sources and research related to value creation have revealed various dimensions and indicators used by previous researchers. A description of the dimensions of value creation can be seen in table 2 .

TABLE II. VALUE CREATION DIMENSION

\begin{tabular}{|c|c|c|c|c|}
\hline $\begin{array}{l}\text { Chung } \\
(2015)\end{array}$ & $\begin{array}{l}\text { La Rocca \& } \\
\text { Snehota } \\
(2014)\end{array}$ & $\begin{array}{l}\text { Herskovits, } \\
\text { Grijalbo, \& } \\
\text { Tafur (2013) }\end{array}$ & $\begin{array}{l}\text { Craven \& } \\
\text { Piercy } \\
(\mathbf{2 0 1 3})\end{array}$ & $\begin{array}{l}\text { Kotler \& } \\
\text { Keller } \\
(\mathbf{2 0 1 3 )} \\
\end{array}$ \\
\hline $\begin{array}{l}\text { Quality } \\
\text { Service } \\
\text { Cost } \\
\text { control } \\
\text { Speed } \\
\text { Innovation } \\
\text { Capability }\end{array}$ & $\begin{array}{l}\text { Networked } \\
\text { Sales } \\
\text { Organisation } \\
\text { Architecture } \\
\text { of } \\
\text { Collaboration } \\
\text { Distributed } \\
\text { Knowledge } \\
\text { System }\end{array}$ & $\begin{array}{l}\text { New Products } \\
\& \text { Services } \\
\text { Complementary } \\
\text { \& Leveraging } \\
\text { Technologies } \\
\text { Virtuous } \\
\text { Ecosystem }\end{array}$ & $\begin{array}{l}\text { Market } \\
\text { Sensing } \\
\text { Capabilities } \\
\text { Customer } \\
\text { Linking } \\
\text { Capabilities } \\
\text { Aligning } \\
\text { Structure \& } \\
\text { Process }\end{array}$ & $\begin{array}{l}\text { Benefit } \\
\text { Customer } \\
\text { Bussines } \\
\text { Area } \\
\text { Bussines } \\
\text { Patner/Ne } \\
\text { twork }\end{array}$ \\
\hline
\end{tabular}

The dimension of creation of value in this study was taken from the opinion of Kotler \& Keller, namely the benefits of customers, the Biniss Area, and the temporary Business Partner for the measurement tends to be quoted from Chung's 
research $[19,23]$. This is because the dimensions used are considered in accordance with the conditions at the research site, namely at the center of the knitting industry in the city of Bandung, where the technology used is still relatively simple so that efficiency in the manufacture of products remain unoptimal.

\section{Marketing Performance}

Marketing performance is a benchmark in assessing the success of value creation which is a combination of strengthening innovation capabilities and an in-depth understanding of market orientation. Various experts use different dimensions in measuring marketing performance. For more details, the following will describe the use of marketing performance dimensions from several researchers as shown in table 3 .

TABLE III. Marketing Performance Dimension

\begin{tabular}{|c|c|c|c|c|}
\hline $\begin{array}{l}\text { Levent \& } \\
\text { Kosan } \\
(2014)\end{array}$ & $\begin{array}{c}\text { Mone } e t \\
\text { al., (2013) }\end{array}$ & $\begin{array}{c}\text { Da Gama } \\
(2011)\end{array}$ & $\begin{array}{c}\text { Sullivan } \\
(2007)\end{array}$ & $\begin{array}{l}\text { Green } \text { et al. } \\
\text { (2005) }\end{array}$ \\
\hline $\begin{array}{l}\text { Non Financial } \\
\text { Output } \\
\text { Market share, } \\
\text { customer } \\
\text { satisfaction, } \\
\text { customer } \\
\text { loyalty/retentio, } \\
\text { brand equity, } \\
\text { and innovation } \\
\text { Financial } \\
\text { Output } \\
\text { Sales analyses } \\
\text { Market share } \\
\text { analyses } \\
\text { The ratio of } \\
\text { marketing and } \\
\text { sales } \\
\text { expenditure to } \\
\text { sales }\end{array}$ & $\begin{array}{l}\text { Financial } \\
\text { output } \\
\text { profits, } \\
\text { sales, cash } \\
\text { flow } \\
\text { Non- } \\
\text { financial } \\
\text { output } \\
\text { market } \\
\text { share, } \\
\text { customer } \\
\text { satisfaction }\end{array}$ & $\begin{array}{l}\text { Marketing } \\
\text { Performance } \\
\text { - Quality, } \\
\text { - Costumer } \\
\text { Satisfaction } \\
\text { - Custumer } \\
\text { Loyalty, } \\
\text { - Brand } \\
\text { equity } \\
\text { - Market } \\
\text { Share } \\
\text { Financial } \\
\text { Performance } \\
\text { Sales revenue } \\
\text { Profit margin } \\
\text { Cash Flow }\end{array}$ & $\begin{array}{l}\begin{array}{l}\text { Sales } \\
\text { growth }\end{array} \\
\text { Profitability } \\
\text { New } \\
\text { Product } \\
\text { Success }\end{array}$ & $\begin{array}{l}\text { Market share } \\
\text { growth } \\
\text { Percentace } \\
\text { new product } \\
\text { sales } \\
\text { ROI }\end{array}$ \\
\hline
\end{tabular}

Based on the opinions of several experts on the indicators used to measure marketing performance, the study of measuring marketing performance in the knitting industry in Bandung combines two theoretical concepts in measuring marketing performance indicators [3].

\section{Framework Thinking and Hypothesis}

In order to improve marketing performance, value creation must be based on the right market orientation to understand customer needs and desires. Market orientation is then realized in the value of products that are unique and able to meet the needs and desires of customers.

1) The Relationship between market orientation and marketing performance.

The amount of income received is a measure of marketing performance. The uniqueness of the product compared to competitors will increase the income received. Da Gama (2011) states that the benefits of expanding knowledge about marketing performance are substantial. This marketing performance improvement will be obtained if the company conducts the right market orientation so that it can create unique products that are able to meet customer needs and desires.

Reference [8] states that responsive market orientation and competitive intensity have a positive and significant correlation with the performance of both financial and non-financial performance. Reference [24] states that customer orientation and competitors influence technical orientation and marketing performance. In addition, Reference [25] stated that market orientation has a positive and significant impact on the performance of SMEs in Malaysia. The same thing is also refrence [6] stated that market orientation has a positive and significant role on marketing performance as shown in Figure 1.

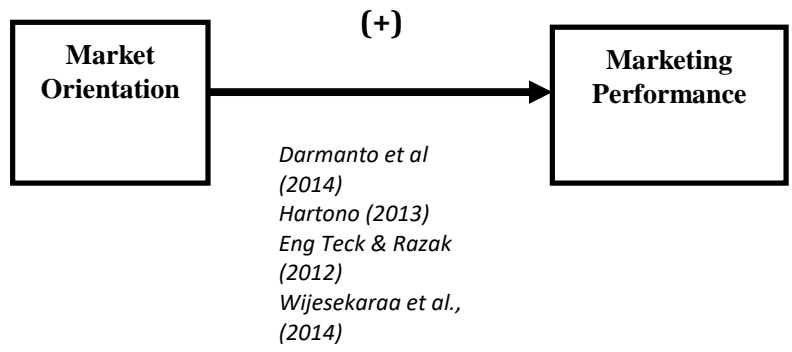

Fig. 1. The relationship of Market Orientation with Marketing Performance

Based on previous research, the link between market orientation and marketing performance. Therefore, the hypothesis can be formulated:

1st Hypothesis: there is a positive and significant influence between market orientation and marketing performance of knitting centers.

2) The Relationship between market orientation and value creation

The existence of a strong relationship between market orientation and value creation can be traced through research that has been done. Refrence [26] stated that market orientation contributes to the creation of more value to customers in a market. Gokus looks at corporate strategy from the perspective of market orientation in terms of value creation, from the results of its research market orientation can change the view of the company to reevaluate the strategies implemented in relation to delivering value to customers. The influence 
of market orientation looks strong in influencing the company's strategy in creating value for customers [27].

Furthermore, reference [28] states that market orientation is measured by customer orientation, competitor orientation and inter-function coordination positively influences company performance. This result is in line with the opinion of reference [29] which states that business is a market orientation where culture is an ethic and an overall commitment to the continuation of creating superior customer value. Based on the findings of previous studies and opinions of experts, it can be seen the close relationship between market orientation and value creation as shown in Figure 2.

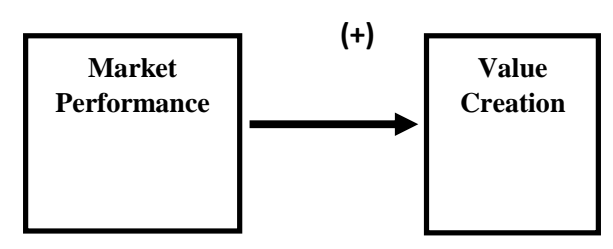

Fig. 2. The Relationship between market orientation and value creation

Thus, the hypothesis can be formulated as follows:

2nd Hypothesis: there is a positive and significant influence between market orientation and value creation

3) The Relationship between value creation and market performance

Value creation offered to customers is the basis for customer satisfaction. The superior value embodied in the company's products will improve the company's performance. It Tournuis saw that value can create marketing performance [4]. While Da Gama made a model based on the company's marketing assets namely quality, satisfaction, and customer loyalty and brand strength and market share to shape marketing performance [5]. In addition, reference [4, 5, 3] stated that corporate marketing is always directed to produce marketing performance and financial performance. Based on the research above, it can be seen the relationship between value creation and marketing performance as shown in Figure 3.

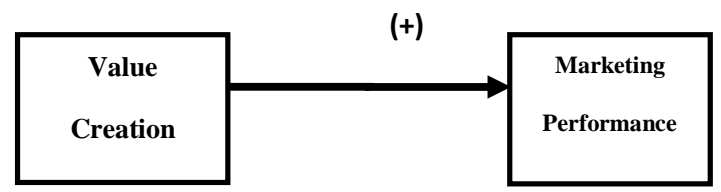

Fig. 3. The Relationship between value creation and market performance
Therefore, the hypothesis can be formulated as follows:

3rd Hypothesis: there is a positive and significant influence between value creation and marketing performance of knitting centers.

4) The Relationship between Market Orientation to Marketing Performance through Value Creation

Value creation is a mediator between market orientation and marketing performance. The superior value embodied in the product is the result of a proper understanding of customer needs and desires (market orientation) so as to improve marketing performance. This happens if the company has the ability to transform creative ideas into reality then transforms it into a product which is able to create and deliver superior value to customers so as to provide benefits to customers and increase profit and market share of the company (Mone et al., Da Gama, Kosan,) which forms a strong bond between customers and companies both cognitively and emotionally $[30,31,14,23,3,4,5,32]$.

Therefore, the hypothesis can be formulated as follows:

4th hypothesis : there is an influence between market orientation on the marketing performance of knitting centers through value creation.

Based on the frame of mind and findings from previous research, a research model can be built to link all variables as shown in Figure 4.

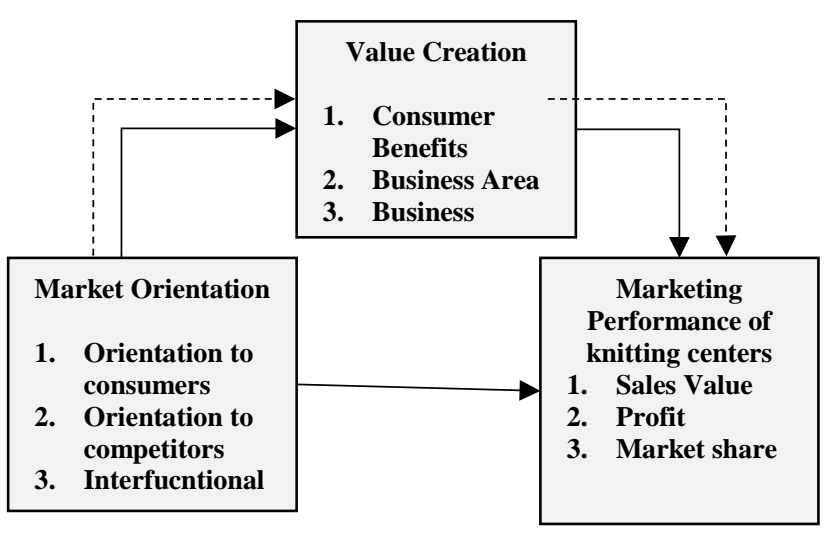

Fig. 4. Research Model 


\section{II.METHOD}

\section{Population and Sample}

This study uses a census method for 281 respondents who are entrepreneurs and members of the Sentra Rajut Binong Jati Bandung. The data is then processed using Structural Equation Modeling (SEM).

\section{Data processing and hypothesis testing}

LISREL 8.7 is used to measure the average score of each $\mathrm{H}_{0}: \gamma_{2.1} \leq 0 \quad$ Market orientation does not have a positive impact on the marketing performance of SMEs at the knitting industry in the city of Bandung.

Ha $: \gamma_{2.1}>0 \quad$ Market orientation has a positive impact on the marketing performance of SMEs at the knitting industry in the city of Bandung.

indicator to get the Grand Mean value to measure the impact of exogenous latent variables. Structural Equation Modeling (SEM) is used in quantitative analysis to test each hypothesis according to the research objectives.

\section{RESULT}

\section{Descriptive Analysis}

The perception of entrepreneurs in knitting centers about market orientation, value creation, and marketing performance is illustrated through responses to the questionnaires provided. The questionnaire consists of 50 questions. Grand Mean Value can be measured based on the average category of respondents' response scores as shown in table 1.

TABLE I. AVERAGE CATEGORIZATION GUIDELINES FoR RESPONDENTS RESPONSE SCORES

\begin{tabular}{|c|l|}
\hline Interval & \multicolumn{1}{|c|}{ Categories } \\
\hline $1,00-1,79$ & Very Bad / Very Low \\
\hline $1,80-2,59$ & Not Good / Low \\
\hline $2,60-3,39$ & Enough \\
\hline $3,40-4,19$ & Good / high \\
\hline $4,20-5,0$ & Very Good / Very High \\
\hline
\end{tabular}

Based on these guidelines, the respondent's responses are as follows:

\section{Market Orientation}

The Grand Mean value for the market orientation variable is 3.39 which is included in the sufficient category. So that it can be concluded that the knitting centers in the city of Bandung are capable of market orientations.

2. Value Creation

Three dimensions of value creation show good results with the Grand Mean value of 3.51. Thus, it can be concluded that most knitting centers in the city of Bandung are able to create value.

3. Market Performance

The Grand Mean value of the marketing performance variable is included in the sufficient category with a value of 3.18. This can mean that most knitting centers in the city of Bandung have sufficient marketing performance.

\section{Hypothesis testing}

1. The Impact of Market Orientation on Marketing Performance of Knitting Centers Hypothesis:

2. The Impact of Market Orientation on Value Creation Hypothesis:

$\mathrm{H}_{0}$ : Partial market orientation does not have a $\gamma_{1.1} \leq 0$ positive impact on the creation of value of knitting centers in the city of Bandung.

Ha : Partial market orientation has a positive impact $\gamma_{1.1}<0 \quad$ on the creation of value of knitting centers in the city of Bandung.

3. The Impact of Value Creation on Marketing Perfomance of Knitting Centers

Hypothesis:

$\mathrm{H}_{0}$ : Value creation does not have a positive impact on

$\beta_{2.1} \leq 0 \quad$ marketing performance at the knitting centers in the city of Bandung.

Ha: $\quad$ Value creation does has a positive impact on $\beta_{2.1}>0$ marketing performance at the knitting centers in the city of Bandung.

4. The Impact of Market Orientation on Marketing Performance of Knitting Center SMEs through Value Creation Hypothesis:

$\mathrm{H}_{0}: \gamma_{2 . \mathrm{i}} \& \quad$ Market orientation does not affect marketing $\beta_{2.1}=0 \quad$ performance indirectly through value creation

Ha $: \gamma_{2 . i} \& \quad$ Market orientation affects marketing $\beta_{2.1} \neq 0 \quad$ performance indirectly through value creation 
Based on calculations using Structural Equation Modeling (SEM) obtained the following results:

TABLE II. DIRECT INFLUENCE TEST RESUltS

\begin{tabular}{|c|c|c|c|}
\hline Relations & $\begin{array}{c}\text { Direct } \\
\text { Influence }\end{array}$ & $\begin{array}{c}\text { Through } \\
\text { Value } \\
\text { Creation }\end{array}$ & Total Influence \\
\hline OP-KP & $0.6 \%$ & $23,8 \%$ & $24,4 \%$ \\
\hline PN-KP & $42,4 \%$ & - & $42,4 \%$ \\
\hline OP-PN & $13,4 \%$ & - & $13,4 \%$ \\
\hline
\end{tabular}

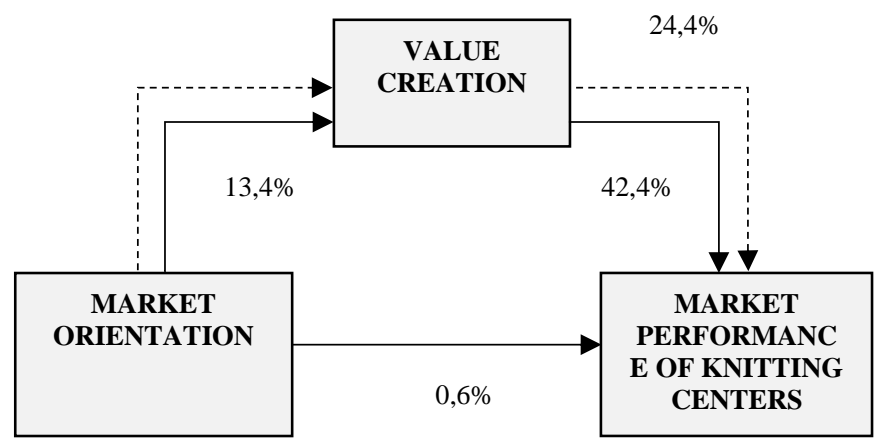

Fig. 5. Structural Model

Based on table 2 it can be seen that market orientation does not directly affect the marketing performance of knitting centers. This is different from previous studies refrence [5,4,3] which states that market orientation has a positive and significant impact on marketing performance. This happens because the needs and desires of the customer have not been able to be implemented into the product. So that market orientation does not necessarily improve marketing performance.

\section{IV.DISCUSSION}

Based on the results above, it is shown that:

1. Based on the perceptions of entrepreneurs at the knitting centers on market orientation, value creation, and marketing performance are as follows:

a. Orientation is in good condition, meaning that the knitting center basically has an understanding of the needs and desires of the customer, but has not been able to transform it into functions within the company. However, entrepreneurs in the knitting centers have not fully followed the development of competitors abroad and have not optimally explored the strengths and weaknesses of competitors. In addition, the pattern of information dissemination to subordinates is still not optimal.

b. Value creation is in very good condition. This means that the knitting center is capable enough to create value for customers. However, the ability to create these values cannot be fully realized into products that have unique and superior characteristics compared to competitors.

c. The knitting center's marketing performance is in good condition. This means that the knitting center is able to create company performance based on market orientation and value creation in a pretty good position. However, this cannot be measured with certainty because entrepreneurs at the knitting center have not recorded transactions properly.

2. Market orientation has a positive impact on value creation. This shows that a proper understanding of the needs and desires of customers and weaknesses and strengths of competitors and the distribution of information evenly to all parts of the company contributes to the creation of superior value.

3. Value creation has a positive impact on company performance. The superior value invested by the company into the product causes an increase in marketing performance. Therefore, it can be concluded that the more superior value invested in the product will encourage increased marketing performance of knitting centers.

4. Market orientation has a positive impact on marketing performance through value creation. Thus, it can be concluded that value creation is an intermediary between market orientation and marketing performance of the SMEs at Sentra Rajut.

\section{V.CONCLUSIONS}

Both market orientation and value creation partially and simultaneously have an impact on the marketing performance of the SMEs at Sentra Rajut in Bandung. However, market orientation partially has no impact on marketing performance of the SMEs at Sentra Rajut. The market orientation should be transformed into value in order to increase the marketing performance of the SMEs at Sentra Rajut in Bandung.

\section{ACKNOWLEDGEMENT}

The author would like to thank the UN Chancellor Dr. Ir. H. Eddy Soeryanto Soegoto., And Dean of the Faculty of Economics and Business Prof. Dr. Hj. Dwi Kartini Yahya., SE., Spec. Lic, who has given the opportunity to conduct this research.

\section{REFERENCES}


[1] Anigbogu, T. U., Onwuteaka, C. I., Edoko, T. D., \& Okoli, M. I., "Roles of Small and Medium Scale Enterprises in Community Development: Evidence from Anambra South Senatorial Zone, Anambra State," International Journal of Academic Research in Business and Social Sciences, Vol. 4, No. 8 ISSN: 2222-6990, Aug. 2014.

[2] Tambi, S., \& Praveen, A, "The Challenges Faced by SMEs in the Textile Industry: Special Reference to Hand Printing Enterprises in Jaipur" Global Journal of Management and Business Studies, vol. 3, ISSN 2248-9878, no. 7, 2013.

[3] Mone, Sorina-Diana, Marius D. Pop, Nicoleta-Dorina RacoltaPaina,. The "What" And "How" Of Marketing Performance Management Management and Marketing Challenges for the Knowledge Society Vol. 8, no. 1, 2013, pp. 129-146.

[4] Tournuis, Laurent, "Total Market Orientation, Customer Value, And Market Performance from A Dual Perspective," The Journal of Apllied Busines Research, 2013, vol. 29, No. 4.

[5] Da Gama, Antonio Pimenta, , "An Expanded Model of Marketing Performance," Marketing Inteligence \& Planning, 2011, Vol. 29 No. 7.

[6] Wijesekara, W. A. D. S., Kumara, P. A. P. S., \& Gunawardana, T. S. L. W. Impact of Market Orientation and Entrepreneurial Orientation on Performance: A Study of Small and Medium Scale Garment Manufacturers in Sri Lanka. In Proceedings of the 3rd International Conference on Management and Economics Vol. 26, p. 27, Feb 2014.

[7] Zhang Jing \& Duan Yanling, "The impact of different types of market orientation on product innovation performance," Management Decision, 2010, vol. 48 no. 6, pp. 849-867.

[8] Hartono, Arif, "Investigating Market Orientation Business Performance Relationships in the Yogyakarta (Indonesia) Batik Family Firms, ” International Journal of Marketing Studies, Vol. 5, No. 5, 2013.

[9] Aljanabi, Abdul. Q.R.A \& Nor A.M.Noor. The Mediating role of Market Orientation on Entrepreneurial Orientation, Absorptive Capacity and Technological Innovation Capabilities. Asian Social Science, 2015, Vol. 11, No. 5.

[10] Suliyanto,"Impact of Entrepreneurship Orientation and Marketing-Based Reward System towards Marketing Performance" International Journal of Business and Social Science, Vol. 2 No. 6, 2011.

[11] Mahmood, R \& N. Hanafi. "Entrepreneurial Orientation and Business Performance of Women-Owned Small and Medium Enterprises in Malaysia: Competitive Advantage as a mediator". International Journal of Business and Social Science, vol. 4(1), pp. 82-90, 2013.

[12] Algarni, M.A. \& Thalib.A.N. "A Framework of Measuring the impact of Market Orientation on the outcome of Higher Education Institutions mediated by innovation. International" Review of Management and Business Research. Vol. 3 Issue.2, 2014.

[13] D’Angelo, Alfredo, "International Entrepreneurship: Starting, Developing, and Managing Global Venture." Journal of Small Business and Enterprise Development. ISSN: 1462-6001, 2011.

[14] Lindman. M, Pennanen. K, Rothenstein J, Scozz. B, \& Vincze. Z. "The Ractice of Customer Value Creation And Market Impactiveness Among Lowtech Smes." Journal Of global Business and Technology, vol. 8, no.1, 2012.

[15] Kara, Ali \& Oscar W. Deshields. The Effect of a Market Orientation on Business Performance: A Study of Small-Sized Service Retailers Using MARKOR Scale. Journal of Small Business Management 43(2). 2005.

[16] Kotler, Phillip \& Keller.K.L. Marketing Management. New Jersey; Pearson. 2012

[17] Narver, John C. \& Stanley F. Slater. "The Effect of a Market Orientation on Business Profitability". Journal of Marketing, 1990.
[18] Njeru, Winnie G. \& Francis N. Kibera. "The perceived effects of the three components of market orientation on the performance of tour firms in Kenya." European Scientific Journal, Vol. 10 No. 25 ISSN: 1857-7881. 2014.

[19] Chung, Yi-Yung. Exploring a missing link for the market orientation effect on business performance: The strategig role of cutomer value creation capabilities.2015.

[20] Hussain, Jawad, Fayaz Ali Shah \& Ch. Shoaib Akhtar. Market orientation and organizational performance in Small and Medium sized enterprises. A conceptual approach. City University Research Journal Vol. 06 No. 1. 2016.

[21] La Rocca, Antonella dan Ivan Snehota, , Value Creation and organisational practises at firm boundaries. 2014.

[22] Lindman. M, Pennanen. K, Rothenstein J, Scozz. B, \& Vincze. $\mathrm{Z}$. The Ractice of Customer Value Creation and Market Effectiveness among Lowtech Smes. Journal Ofglobal Business and Technology, vol. 8, no.1. 2012.

[23] Kotler, P \& KL. Keller. Marketing Management. Upper Saddle River, N.J., Pearson Prentice Hall . 2013.

[24] Darmanto, Hunik Sri Runing S, Harsono Mugi, Tulus Haryono. "The Relationship between Strategy Orientation and Marketing Performance: The Role of Organizational Change Capability." American International Journal of Contemporary Research Vol. 4. No. 1. 2014.

[25] Eng Teck, Pua. "Entrepreneurial Market Orientation R Performance Malaysian SME's perspective." Jour Entrepreneurship and Sustainability vol. 8. Iss 1.2012.

[26] Fierro, Jesu's Cambra, Florin Juan, Perez Lourdes, Jeryl Whitelock. Inter-firm market orientation as antecedent of knowledge transfer, innovation and value. 2011.

[27] Gokus, Omer. "Mentoring Function's Relationship with Socialization Facets and Stages." A Conceptual Framework. Journal of Organizational Culture, Communications and Conflict, Vol. 19 No. 2. ISSN: 1544-0508. 2015.

[28] Njeru, Winnie G. \& Francis N. Kibera. The perceived impacts of the three components of market orientation on the performance of tour firms in Kenya. European Scientific Journal vol. 10 no. 25 ISSN: 1857-7881.2014.

[29] Cravens, D.W. Piercy.N.F. Strategic Marketing. New York: McGraw Hill. 2013.

[30] Subramaniam, Indra Devi \& Mohammad Mehdi Moslehi. Does Workforce Innovation Mediate the Relationship between Internal Factors and Performance in Malaysian Entrepreneurial SMEs?. Asian Social Science, vol. 9 no. 9. 2013.

[31] Baregheh Anita, Rowley Jennifer, Sambrook Sally, Davies Daffyd. " Innovation in food sector SMEs.” Journal of Small Business and Enterprise development. vol. 19 no. 2, pp. 300321.2012.

[32] Kosan Levent. Accounting for Marketing: Marketing Performance Through Financial Results. International Review of Management and Marketing Vol. 4, No. 4, , pp.276-283.2014. 